\title{
NANO FAT COMBINED WITH PLATELET RICH PLASMA INJECTION VERSUS NANO FAT INJECTION ALONE IN THE TREATMENT OF ATROPHIC SCAR
}

\author{
By
Mamoun El-Sayed Shalaby, Shady Mahmoud Attia Ibrahim and Mohammed Nasser Abdulhay Hassanin \\ Department of Dermatology, Venereology and Andrology, Faculty of Medicine, Al-Azhar \\ University \\ *Corresponding author: Mohammed Nasser Abdulhay Hassanin, \\ Mobile: (+20)01151577729, E-Mail: mohdnasser1990@ gmail.com
}

\begin{abstract}
Background: An atrophic scar is an indented scar that heals below the normal layer of skin tissue. Atrophic scars form when the skin is unable to regenerate tissue. As a result, it leaves behind imbalanced scarring.

Objective: To evaluate the efficacy and safety of the autologous emulsified fat transfer with or without platelet rich plasma in the treatment of atrophic scar.

Patients and methods: This study was carried out at Dermatology Department, Al-Hussein University Hospital, Faculty of Medicine, Al-Azhar University. This study included 60 patients with atrophic scar divided into 2 equal groups: group (A) treated with nanofat and platelet rich plasma, and group (B) treated with nanofat only. Scar in both groups caused by different etiological factors, their ages ranged from 19 to 59 years with 40 males and 20 females on a period from March 2019 to December 2019.
\end{abstract}

Results: No significant differences between group A and group B after treatment, revealing that the corner stone of significance created by nanofat injection including adipose derived stem cells and growth factors without obvious clinical and statistical significance of additional platelet rich plasma.

Conclusion: Nanofat injection has been shown to have beneficial effects in the treatment of atrophic scar, wrinkles, and skin discolorations, being highly effective in improving the height and pliability of all scars with mild improvement in pigmentation and vascularities, addition of platelet rich plasma to nanofat showed the same result which treated.

Keywords: Nano fat, Platelet rich plasma, Atrophic scar.

\section{INTRODUCTION}

Atrophic scars are the end result of acne, chicken box, surgery, trauma and burn (Patel et al., 2014). The available treatment modalities for atrophic scarring available are chemical peeling, topical tritenoin, dermabrasions, subcision, punch excision, tissue augmenting agents and laser (Fabbrocini et al., 2010).

Fat is close to the ideal augmentation material in that it is cheap, readily available, and incapable of being rejected or causing allergic or other adverse tissue reactions (Fabrocini et al., 2012). 
The technique consists of two phases: procurement of the graft and placement of the graft. The injection phase, with small parcels of fat implanted in multiple tunnels allows the fat graft maximal access to its available blood supply. Most acne-scarred patients achieve maximum results about three months after the procedure (Goodman, 2010).

Platelet-rich plasma (PRP) is an autologous blood-derived product enriched in platelets, growth factors and chemo/cytokines delivered in a concentrated volume of plasma. Since the 1970s, PRP has received significant attention as applied to tissue repair and regeneration (Alser and Gotus, 2018).

The aim of this study was to evaluate the efficacy and safety of the autologous emulsified fat transfer with or without platelet rich plasma in the treatment of atrophic scar.

\section{PATIENTS AND METHODS}

This study was carried out at Dermatology Department, Al-Hussein University Hospital, Faculty of Medicine, Al-Azhar University.This study included 60 patients with atrophic scar of different etiological factors, their ages ranged from 19 to 59 years with 40 males and 20 females on a period from March 2019 to December 2019. An approval of the study was obtained from Al- Azhar University academic and ethical committee. Every patient signed an informed written consent for acceptance of the operation.
Sixty patients were divided into 2 equal groups:

1. Group (A) treated by autologous fat injection and platelet - rich - plasma (PRP) injection.

2. Group (B) treated by autologous fat injection only.

Surgical procedure: All patients selected for the procedure clinically were assessed and examined preoperatively.

\section{Autologous fat harvesting for both groups:}

The harvesting sites considered in mind convenience of access and enhancement of the patient's contour. The abdomen was the most commonly chosen site then the flanks and finally inner side of the knee involved, after injection of 2 $\mathrm{cm}$ of (lidocaine hydrochloride 2\%) intradermally at site of entry plade No 11 was stapped to open access for $3 \mathrm{~mm}$ multiport harvesting cannula to access subcutaneous fat.

Tumescent anesthesia $(500 \mathrm{ml}$ of $0.9 \%$ saline solution, adrenaline $0.5 \mathrm{mg} / \mathrm{ml}$, and $20 \mathrm{ml}$ of lidocaine hydrochloride $2 \%$ without adrenaline) was infiltrated in multidirection plane to numb the whole area and waiting for 20 minutes to fulfill complete numbness, then starting to push the harvesting cannula in and out with slight suction pressure created by pulling the plunger of $20 \mathrm{ml}$ luer-lock syringe, finally subcutaneous fat started to be expelled in the syringe.

\section{Autologous fat processing for both groups:}

The aspirated fat was washed using Lactated Ringer by strong irrigation, then waited for $3 \mathrm{~min}$, then centrifuged at 3000 
rpm for $3 \mathrm{~min}$ to concentrate fat particles, and separate them from oily layer above containing ruptured lipocytes and fluids and debris below, which was then discarded.

\section{Autologous fat preparation for both groups:}

After centrifugation, the lipoaspirate was mechanically emulsified by shifting to another $20 \mathrm{ml}$ luer-look syringes by 30 pass using (2.4 mm tulip connector $\left.{ }^{\odot}\right)$ to form macrofat which then emulsified to microfat by 30 pass in between 2 syringes using (1.4 $\mathrm{mm}$ tulip connector $\left.{ }^{\odot}\right)$, then further emulsification was done by changing the connector to $(1.2 \mathrm{~mm}$ tulip connector $^{\odot}$ ) with 30 pass. Finally, the microfat was passed one pass through 600 micro $m$ nanofat filter to form the "nanofat" beign ready for injection.

For group (B), which included enrichment for nanofat by platelet rich plasma , PRP was prepared by aspiration of $9 \mathrm{ml}$ blood into a tube containing $1 \mathrm{ml}$ of citrate dextrose. This mixture was shaken and placed in the centrifuge to be centrifuged using a 'soft' spin $250 \mathrm{x}$ g for $10 \mathrm{~min}$, then transfer the supernatant plasma containing platelets into another sterile tube (without anticoagulant) to be recentrifuged at a higher speed (a 'hard' spin $750 \mathrm{x} \mathrm{g}$ for $10 \mathrm{~min}$ )to obtain a platelet concentrate. The lower $1 / 3^{\text {rd }}$ was PRP and upper $2 / 3$ rd was platelet poor plasma (PPP). At the bottom of the tube platelet pellets are formed. PPP was removed and the platelet pellets were suspended in a minimum quantity of plasma $(2-4 \mathrm{~mL})$ by gently shaking the tube. Nanofat was mixed with PRP by 3 to 4 soft shifting between both syringes using 3 ways connector, and then being ready for injection.

\section{Autologous fat injection for both groups:}

Superficial intradermal nanofat injection was done by $28 \mathrm{~g}$ insulin syringes, and additional subdermal injection of nanofat performed in some cases using cannula (22-23 G) mounted on a Luer-Lock syringe. Injection performed until yellowish discoloration of the skin showed up. The treated area was covered with dressing for 1 week, and the patients were instructed not to apply pressure or friction to the recipient sites to limit displacement of fat infiltration and sunscreen descriped for all cases. External pressure with elastic dressing (steristrips ${ }^{\circledR}$ ) was applied to the donor sites to minimize postoperative edema and to prevent hematoma formation.

\section{Postoperative care:}

All patients received antibiotics for 7 days, antiedematous drugs, and analgesics.

\section{Statistical analysis:}

Recorded data were analyzed using the statistical package for social sciences, version 20.0 (SPSS Inc., Chicago, Illinois, USA). Quantitative data were expressed as mean \pm standard deviation (SD) and median. Qualitative data were expressed as frequency and percentage.

\section{The following tests were done:}

- Mann-Whitney U test of significance was used when comparing between two means.

- Chi-square (x2) or Fisher's exact test of significance was used in order to 
compare proportions between two qualitative parameters.
- The confidence interval was set to $95 \%$ and the margin of error accepted was set to $5 \%$. The p-value was considered significant when $\mathrm{P}<0.05$.

\section{RESULTS}

Regarding demographic data between two groups, there was a statistical significant difference in age of both groups. In group (A), mean age was 32.8 \pm 11.2 in contrast to $26.5 \pm 9.1$ in group (B). Regarding sex of both groups, there were no statistical significant differences. In group (A), males to females cases was 21:9 representing $70 \%$ to $30 \%$ respectively, while in group (B) males to females cases was 19:11 representing 36.3 $\%$ to $36.7 \%$ respectively (Table $\mathbf{1}$ ).

Regarding duration of atrophic scar, there was a statistically significant differences with a mean of $6.8 \pm 7.6$ in group (A), and $3.3 \pm 2.7$ in group (B). On the other hand, etiology of atrophic scar in both groups showed non statistical differences. Traumatic scar was the predominant etiology as traumatic scar cases in group (A) was 21 , while in group (B) was 24 representing $70 \%$ to $80 \%$ respectively. Post acne scar was of equal number of cases in both groups by 3 cases in each group representing $10 \%$ in two groups. Post chemical burn represented by 2 cases treated with nanofat and PRP representing $6.7 \%$ of total 30 cases in group (A). Cat scratch atrophic scar were 2 cases in group (A) and 1 case in group (B), representing $6.7 \%$ to $3.3 \%$ respectively. Post chicken box and post burn atrophic scar were represented by one case to each group with $3.3 \%$ for each one. On the other hand, post steroid injection atrophic scar and post-surgical scar were represented in the nanofat group by 1 case for each one with $3.3 \%$ (Table 1).

Table (1): Comparison between studied groups as regard demographic data

\begin{tabular}{|c|c|c|c|c|c|c|}
\hline \multicolumn{2}{|c|}{$\mathrm{Dems}_{\text {Demographic data }}$ Groups } & \multirow{2}{*}{\multicolumn{2}{|c|}{$\begin{array}{c}\mathbf{N}+\text { PRP } \\
(\mathbf{N}=\mathbf{3 0})\end{array}$}} & \multirow{2}{*}{\multicolumn{2}{|c|}{$\begin{array}{c}\begin{array}{c}\mathbf{N} \text { only } \\
(\mathbf{N}=\mathbf{3 0})\end{array} \\
26.5 \pm 9.1\end{array}$}} & P-value \\
\hline $\begin{array}{l}\text { Age } \\
\text { (years) }\end{array}$ & Mean \pm SD & & & & & 0.014 \\
\hline \multirow{2}{*}{ Sex } & Male & 21 & $70 \%$ & 19 & $63.3 \%$ & \multirow{2}{*}{0.584} \\
\hline & Female & 9 & $30 \%$ & 11 & $36.7 \%$ & \\
\hline $\begin{array}{l}\text { Duration } \\
\text { (years) }\end{array}$ & Mean \pm SD & \multicolumn{2}{|c|}{$6.8 \pm 7.6$} & \multicolumn{2}{|c|}{$3.3 \pm 2.7$} & 0.004 \\
\hline \multirow{8}{*}{ Etiology } & Traumatic & 21 & $70 \%$ & 24 & $80 \%$ & \multirow{8}{*}{0.479} \\
\hline & $\begin{array}{l}\text { Post chemical } \\
\text { peel }\end{array}$ & 2 & $6.7 \%$ & 0 & $0 \%$ & \\
\hline & Post acne & 3 & $10 \%$ & 3 & $10 \%$ & \\
\hline & Chicken box & 1 & $3.3 \%$ & 0 & $0 \%$ & \\
\hline & Cat scratch & 2 & $6.7 \%$ & 1 & $3.3 \%$ & \\
\hline & Post-burn & 1 & $3.3 \%$ & 0 & $0 \%$ & \\
\hline & Steroid & 0 & $0 \%$ & 1 & $3.3 \%$ & \\
\hline & Post-surgical & 0 & $0 \%$ & 1 & $3.3 \%$ & \\
\hline
\end{tabular}

X2: Chi-square test, MW: Mann-Whitney U test. 
Regarding to the total Vancouver scare scale before and after treatment in group (A), there was a significant difference with a mean of $4.6 \pm 1.7$ before to $2.4 \pm$ 1.3 after, and this difference was with a significant difference in height, and significant difference in pliability in contrast to vascularity and pigmentation have non-significant difference noted (Table 2).

Table (2): Comparison of VSS (before \& after) in Nanofat + PRP group

\begin{tabular}{|c|c|c|c|c|c|c|}
\hline \multicolumn{2}{|c|}{$\begin{array}{ll}\text { Parameters } & \text { States } \\
\end{array}$} & \multicolumn{2}{|c|}{$\begin{array}{c}\text { Before } \\
(\mathbf{N}=\mathbf{3 0})\end{array}$} & \multicolumn{2}{|c|}{$\begin{array}{c}\text { After } \\
(\mathbf{N}=\mathbf{3 0})\end{array}$} & P-value \\
\hline \multirow{3}{*}{ Vascularity } & Normal & 25 & $83.3 \%$ & 27 & $90 \%$ & \multirow{3}{*}{0.194} \\
\hline & Pink & 2 & $6.7 \%$ & 3 & $10 \%$ & \\
\hline & Red & 3 & $10 \%$ & 0 & $0 \%$ & \\
\hline \multirow{4}{*}{ Pigmentation } & Normal & 21 & $70 \%$ & 22 & $73.3 \%$ & \multirow{4}{*}{0.131} \\
\hline & Нуро & 0 & $0 \%$ & 3 & $10 \%$ & \\
\hline & Mixed & 1 & $3.3 \%$ & 2 & $6.7 \%$ & \\
\hline & Hyper & 8 & $26.7 \%$ & 3 & $10 \%$ & \\
\hline \multirow{4}{*}{ Pliability } & Normal & 0 & $0 \%$ & 2 & $6.7 \%$ & \multirow{4}{*}{0.011} \\
\hline & Supple & 18 & $60 \%$ & 26 & $86.7 \%$ & \\
\hline & Yielding & 7 & $23.3 \%$ & 2 & $6.7 \%$ & \\
\hline & Firm & 5 & $16.7 \%$ & 0 & $0 \%$ & \\
\hline \multirow{4}{*}{ Height } & Flat & 0 & $0 \%$ & 9 & $30 \%$ & \multirow{4}{*}{$<0.001$} \\
\hline & $<2 \mathrm{~mm}$ & 6 & $20 \%$ & 20 & $66.7 \%$ & \\
\hline & $2-5 \mathrm{~mm}$ & 21 & $70 \%$ & 1 & $3.3 \%$ & \\
\hline & $>5 \mathrm{~mm}$ & 3 & $10 \%$ & 0 & $0 \%$ & \\
\hline \multirow{2}{*}{ Total } & Mean \pm SD & \multicolumn{2}{|c|}{$4.6 \pm 1.7$} & \multicolumn{2}{|c|}{$2.4 \pm 1.3$} & \multirow{2}{*}{$<0.001$} \\
\hline & Median & & 4 & & & \\
\hline
\end{tabular}

X2: Chi-square test, MW: Mann-Whitney U test.

Regarding to the total Vancouver scare scale before and after treatment in group (B), there was significant difference with a mean of $5.2 \pm 1.8$ before to $1.9 \pm 1.4$ after. This difference was created by significant difference in both height and pliability, while vascularity and pigmentation showed non-significant differences (Table 3).

Table (3): Comparison of VSS (before and after) in Nanofat only group

\begin{tabular}{|c|c|c|c|c|c|c|}
\hline \multicolumn{2}{|l|}{ Parameters } & \multicolumn{2}{|c|}{$\begin{array}{c}\text { Before } \\
(\mathbf{N}=\mathbf{3 0})\end{array}$} & \multicolumn{2}{|c|}{$\begin{array}{c}\text { After } \\
(\mathbf{N}=\mathbf{3 0})\end{array}$} & P-value \\
\hline \multirow{4}{*}{ Vascularity } & Normal & 26 & $86.7 \%$ & 27 & $90 \%$ & \multirow{4}{*}{0.528} \\
\hline & Pink & 2 & $6.7 \%$ & 3 & $10 \%$ & \\
\hline & Red & 1 & $3.3 \%$ & 0 & $0 \%$ & \\
\hline & purple & 1 & $3.3 \%$ & 0 & $0 \%$ & \\
\hline \multirow{3}{*}{ Pigmentation } & Normal & 19 & $63.3 \%$ & 24 & $80 \%$ & \multirow{3}{*}{0.275} \\
\hline & Нуро & 1 & $3.3 \%$ & 0 & $0 \%$ & \\
\hline & Hyper & 10 & $33.3 \%$ & 6 & $20 \%$ & \\
\hline \multirow{4}{*}{ Pliability } & Normal & 0 & $0 \%$ & 6 & $20 \%$ & \multirow{4}{*}{$<0.001$} \\
\hline & Supple & 13 & $43.3 \%$ & 23 & $76.7 \%$ & \\
\hline & Yielding & 9 & $30 \%$ & 1 & $3.3 \%$ & \\
\hline & Firm & 8 & $26.7 \%$ & 0 & $0 \%$ & \\
\hline \multirow{4}{*}{ Height } & Flat & 0 & $0 \%$ & 16 & $53.3 \%$ & \multirow{4}{*}{$<0.001$} \\
\hline & $<2 \mathrm{~mm}$ & 4 & $13.3 \%$ & 14 & $46.7 \%$ & \\
\hline & $2-5 \mathrm{~mm}$ & 19 & $63.3 \%$ & 0 & $0 \%$ & \\
\hline & $>5 \mathrm{~mm}$ & 7 & $23.3 \%$ & 0 & $0 \%$ & \\
\hline \multirow{2}{*}{ Total } & Mean \pm SD & \multicolumn{2}{|c|}{$5.2 \pm 1.8$} & \multicolumn{2}{|c|}{$1.9 \pm 1.4$} & \multirow{2}{*}{$<0.001$} \\
\hline & Median & & 5 & & & \\
\hline
\end{tabular}

X2: Chi-square test, MW: Mann-Whitney U test. 
Results showed non-significant differences between group A and group B after treatment, revealing that the corner stone of significance was created by nanofat injection including adipose derived stem cells and growth factors without obvious clinical and statistical significance of additional platelet rich plasma (Table 4).

Table (4): Comparison of VSS (After) between studied groups

\begin{tabular}{|c|c|c|c|c|c|c|}
\hline \multicolumn{2}{|l|}{ Parameters } & \multicolumn{2}{|c|}{$\begin{array}{c}\text { GROUP (A) } \\
(\mathbf{N}=\mathbf{3 0})\end{array}$} & \multicolumn{2}{|c|}{$\begin{array}{c}\text { GROUP (B) } \\
(\mathbf{N}=\mathbf{3 0})\end{array}$} & P-value \\
\hline \multirow{2}{*}{ Vascularity } & Normal & 27 & $90 \%$ & 27 & $90 \%$ & \multirow{2}{*}{1.0} \\
\hline & Pink & 3 & $10 \%$ & 3 & $10 \%$ & \\
\hline \multirow{4}{*}{ Pigmentation } & Normal & 22 & $73.3 \%$ & 24 & $80 \%$ & \multirow{4}{*}{0.107} \\
\hline & Нуро & 3 & $10 \%$ & 0 & $0 \%$ & \\
\hline & Mixed & 2 & $6.7 \%$ & 0 & $0 \%$ & \\
\hline & Hyper & 3 & $10 \%$ & 6 & $20 \%$ & \\
\hline \multirow{3}{*}{ Pliability } & Normal & 2 & $6.7 \%$ & 6 & $20 \%$ & \multirow{3}{*}{0.284} \\
\hline & Supple & 26 & $86.7 \%$ & 23 & $76.7 \%$ & \\
\hline & Yielding & 2 & $6.7 \%$ & 1 & $3.3 \%$ & \\
\hline \multirow{3}{*}{ Height } & Flat & 9 & $30 \%$ & 16 & $53.3 \%$ & \multirow{3}{*}{0.134} \\
\hline & $<2 \mathrm{~mm}$ & 20 & $66.7 \%$ & 14 & $46.7 \%$ & \\
\hline & $2-5 \mathrm{~mm}$ & 1 & $3.3 \%$ & 0 & $0 \%$ & \\
\hline \multirow{2}{*}{ Total } & Mean \pm SD & \multicolumn{2}{|c|}{$2.4 \pm 1.3$} & \multicolumn{2}{|c|}{$1.9 \pm 1.4$} & \multirow{2}{*}{0.264} \\
\hline & Median & & 2 & & 2 & \\
\hline
\end{tabular}

$\mathrm{X}^{2}$ : Chi-square test, MW: Mann-Whitney U test.

\section{DISCUSSION}

Regarding to total Vancouver scare scale before treatment in both groups show non-significant difference denoting both groups were almost same at baseline and in the same manner total Vancouver scare scale after treatment in both groups had non-significant difference denoting that both groups showed improvement after both procedures.

Regarding to the total Vancouver scare scale before and after treatment in group (A) and group (B), there was a significant difference, and this difference was created by a significant difference in height and pliability, in contrast vascularity and pigmentation have non-significant difference noted.

Barone et al. (2016) evaluated the efficacy of nanofat and PRP in treatment of post acne atrophic scar in 15 patients which revealed improvement in the height of the scar with pretreatment thickness $.532 \mathrm{~mm}$ and post treatment thickness $1.201 \mathrm{~mm}$ which correlated with our result in post acne atrophic scar in both groups.

Gentile et al. (2014) evaluated fat graft $\&$ PRP in 10 patient versus fat graft only for 10 patient suffering from posttraumatic and post burn scar in the face. They revealed $69 \%$ maintenance in the contour restoration \& volume after 1 year with fat \& PRP over fat injection alone, reflecting that PRP added more survival rate of fat graft. The difference here compared to our study suggests that further follow up of our patient in both groups after 6 month \& 1 year later.

In agreement with our study, Tenna et al. (2017) used autologous fat graft with PRP in treatment of atrophic acne scars in 


\section{NANO FAT COMBINED WITH PLATELET RICH PLASMA INJECTION... 617}

15 patient and show that Nanofat plus PRP injection can fill the scars \& improve height of the lesion.

Modarressi (2013) suppose that adding PRP to fat preparation may be a reliable way to bring appropriate nutrient at the early moments of transplantation to improve fat survival and render the result more predictable due to PRP releases growth factors which stimulate angiogenesis, cell differentiation and proliferation. Salgarello et al. (2015) in contrast underwent breast fat grafting in 42 women half of them receive fat grafting with PRP and the other receive only fat grafts the result was evaluated at 3 month interval like our study revealed that fat grafting plus platelet-rich plasma is not superior to fat grafting alone by the rate of liponecrosis at breast ultrasound, and need for further fat grafting which is nearly same to our study.

Jan et al. (2019) uses nanofat injections in postburn scars of face in 48 patient age range was 4 to 32 years. Significant improvements appear after 6 month was seen in pliability as well as our study $(\mathrm{P}<0.0001)$, however pigmentation also improved but Jan et al. (2019) supposed that the interposition of pearly white nanofat between the thinned-out dermal layers and the deeper tissues contributed to the improvement in pigmentation. Moreover, enhanced contours may be misperceived as paler areas due to increased reflection of light from them, Thus, the significantly improved pigmentation recorded subjectively could be the result of a visual perception without significant difference and this result submitted in our study in some cases but without statistical significant differences detected they suggested that pigmentation should be revaluated after 1 year follow up to a judge well on pigmentation and we suggest that also.

In contrast to our result in the thickness, Jan et al. (2019) showed that thickness was the least improved variables. This can be explained by the nature of nanofat which is milky fluid produced after emulsification of microfat. Very few adipocytes which is responsible for of the filling effect survive the mechanical stress induced by emulsification of fat. Hence, unlike microfat grafting, filling is not a primary component of nanofat grafting. Any augmentation in volume is only a consequent of proliferation incited by growth factors provided by the nanofat, the most relevant component of nanofat is the adipose-derived tissue stromal vascular fraction that survives the emulsification process and is responsible for the rejuvenative, proliferative, and subsequent filling effects by abundant stem cells which has the ability to transform into the host cell lineage such as adipogenic, chondrogenic, cardiogenic, or even neurogenic cells.

In agreement with our study, Fragen (2010) found that transferring fat under skin grafts, scars, and burn scars will increase the padding of the burn scar and make the skin grafts over it more pliable and flexible which is these same result concluded by Klinger et al. (2013) who revealed that injection of processed autologous fat seems to be effective therapeutic approach to scars of different origin, and they affirmed that the treated areas regain characteristics similar to 
normal skin and are clinically assessable, with not only esthetic but also functional results. The treated skin becomes more elastic and softer, allowing even in the case of facial scars a gradual recovery. Durometer reveal a significant reduction in skin hardness after autologous fat grafting, which demonstrates efficacy in scar treatment.

Gareeb et al. (2017) used fat grafting to Improving esthetic outcome of facial scars in 30 patients aged ranged from 8 to 48 years with unpleasant, obvious facial atrophic scars of different etiological factors. Regarding the VSS, there was significant improvement in vascularity and pliability of scars noted after 1 year of follow up which is not valuable in our study due to short term follow up after 3 month.

Wei et al. (2017) treated 20 patients with 25 atrophic facial scars with condensed nanofat combined with fat grafts there were significantly improved for pigmentation $(\mathrm{P}=.004)$ but it is important to note that all cases involved were hypopigmented and mixed (hypopigmented \& hyperpigmented ) and the improvement is assessed by increase pigmentation, in contrast to our study pigmentation was improved toward normal grade of VSS but without statistically significant differences.

\section{CONCLUSION AND RECOMMENDATION}

Nanofat injection has been shown to have beneficial effects in the treatment of atrophic scar, wrinkles, and skin discolorations. It is highly effective in improving the height and pliability of all scars with mild improvement in pigmentation and vascularities, concomitant add of platelet rich plasma in half of our patient showed the same result which treated with nanofat only, revealed that no obvious clinical nor statistical significance in enrichment of nanofat with platelet rich plasma and corner stone of clinical and statistical improvement was created by adipose derived stem cells founded by high concentration in nanofat which accelerated wound healing and stimulate new collagen synthesis. Further long term studies are needed in order to clearly document, the longevity of nanofat and to evaluate the final outcomes of its effectiveness like pigmentation and vascularity. Evidenced by histopatholgical correlation with clinical result.

\section{REFERENCES}

1. Alser $O H$ and Goutos $L$ (2018): The evidence behind the use of platelet-rich plasma (PRP) in scar management, a literature review. Scars, Burns and Healing, 2018; 3: 1-15.

2. Barone $M$, Tenna $S$, Cogliandro A, Panasiti V, Nobile C and Paolo P (2016): Application of regenerative medicine in treatment of acne scars. Plast Aesthet Res, 3:235-239.

3. Fabbrocini G, Annunziata MC, D'Arco V, Lodi G, Mauriello MC, Pastore F and Monfrecola G (2010): Acne scars: pathogenesis, classification and treatment. Dermatol Res Pract. 880 - 93

4. Fragen $R$ (2010): Autologous fat transplantation. In: Shiffman MA, editor. Autologous fat transfer. Verlag Berlin Heidelberg: Springer. 52:11-17.

5. Gentile P, Di Pasquali C, Bocchini I, Floris M, Eleonora T, Fiaschetti V, Floris $R$ and Cervelli V (2014): Breast Reconstruction With Autologous Fat Graft Mixed With Platelet-Rich Plasma. Surg Innov, 249-253.

6. Ghareeb F, Elsakka DM, Alkhateep Y and Zayed HM (2019): Improving esthetic 
NANO FAT COMBINED WITH PLATELET RICH PLASMA INJECTION... 619

outcome of facial scars by fat grafting. Menoufia Med J, 30:412-9.

7. Goodman GJ (2010): Post acne scarring: a review. J Cosmet Laser Ther, 5: 77-95.

8. Jan SN, Bashir MM, Khan FA, Hidayat Z, Ansari HH ,Sohail M, Bajwa AB, Shami HB, Hanif A, Aziz F and Choudhery MS (2019): Unfiltered Nanofat Injections Rejuvenate Postburn Scars of Face. Ann Plast Surg, 82(1):28-33.

9. Kececi Y, Ozsu S and Bilgir O (2014): A cost-effective method for obtainin standard platelet-rich plasma. Wounds, 26:232-8.

10. Klinger $M$, Caviggioli $F$, Klinger FM, Giannasi S, Bandi V Banzatti B, Forcellini D, Maione $L$, Catania $B$ and Vinci V (2013): Autologous fat graft in scar treatment. J Craniofac Surg, 24:1610-1615.

11. Modarressi A (2013): Platelet Rich Plasma (PRP) Improves Fat Grafting Outcomes. World J Plast Surg, 2(1): 6-13.

12. Patel L, MaGrouther D and Chakrabarty K (2014): Evaluating evidence for atrophic scarring treatment modalities. J Royal Soc Medicine Open, 9: 1-13.
13. Salgarello $M$, Visconti $G$ and Rusciani A (2015): Breast fat grafting with platelet-rich plasma: a comparative clinical study and current state of the art. Plast Reconstr Surg, 127: 2176-2185.

14. Tenna S, Cogliandro A, Barone $M$, Panasiti V, Tirindelli $M$ and Carolina $\mathbf{N}$ and Paolo $P$ (2017): Comparative study using autologous fat grafts plus platelet-rich plasma with or without fractional $\mathrm{CO} 2$ laser resurfacing in treatment of acne scars: analysis of outcomes and satisfaction with FACE-Q. Aesthetic Plast Surg, 41(3):661666.

15. Wei H, Gu SX, Liang YD, Chen H, Zhu MG Xu FT, He N, Wei XJ and Li HM (2017): Nanofat-derived stem cells with platelet-rich fibrin improve facial contour remodeling and skin rejuvenation after autologous structural fat transplantation. Oncotarget, 8(40):68542-56. 
حقن الدهون متناهية الصغر و البلازما الغنية بالصفائح

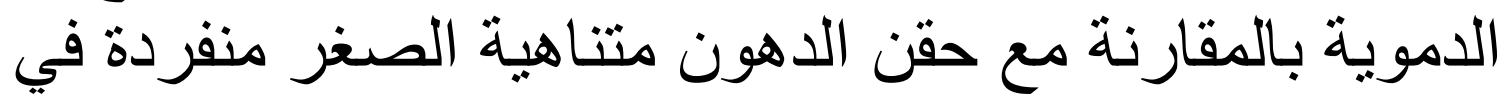

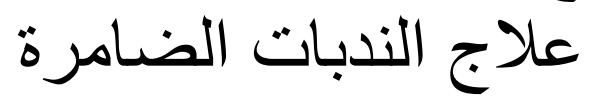

مأمون السيد شلبي، شادي محمود إبراهيم عطية، محمد ناصر عبد الحي قسم الجلاية والتناسلية، كلية الطب، جامعة الأزهر

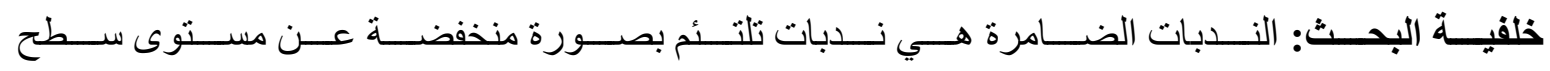
الجلد وتتكون عندما لا يستطيع الجلا إعادة بناء نسيج الندبة.

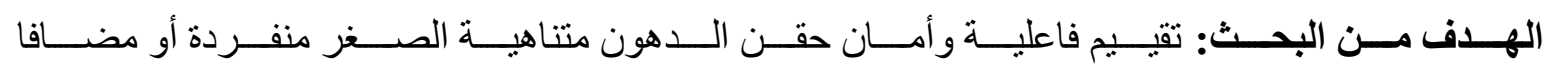
إليها حقن البلازما الغنية بالصفائح الدموية في علاج الندان الندات الضامرة.

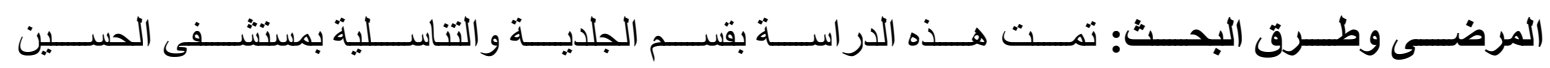

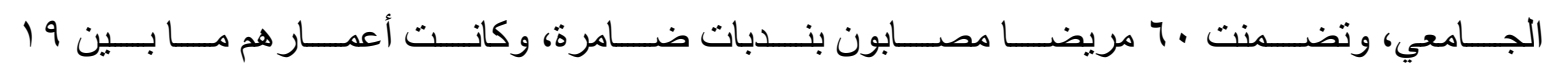

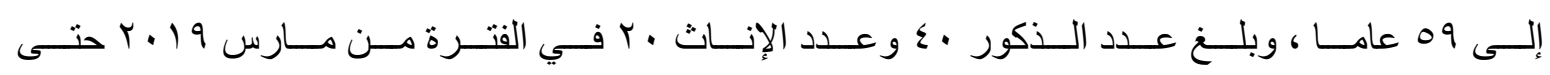
ديسمبر 19 .

وقد تم تقسيم المرضى إلى مجموعتين متساويتين:

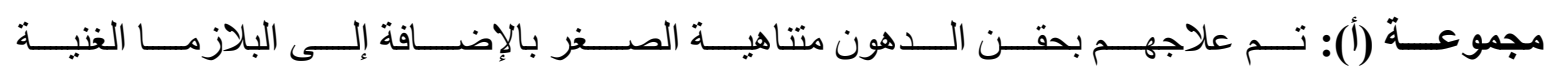
بالصفائح الدموية.

مجموعة (ب): تم علاجهم بحقن الدهون متتاهية الصغر فقط.

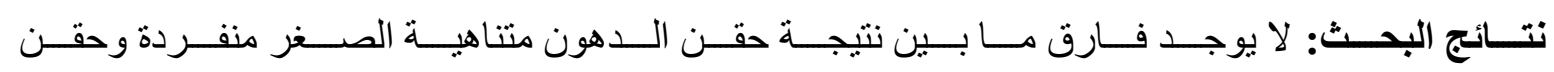

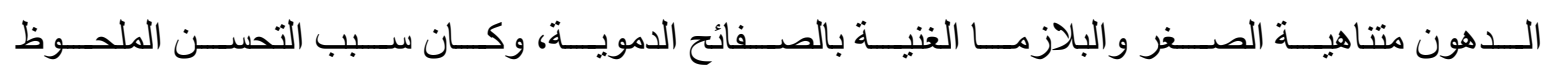

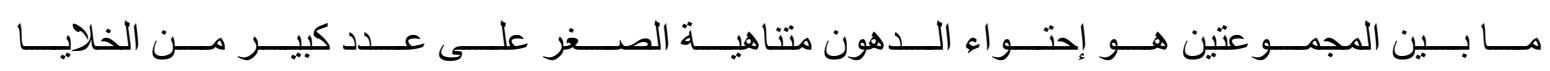
الجذعية داخل النسيج الدهني.

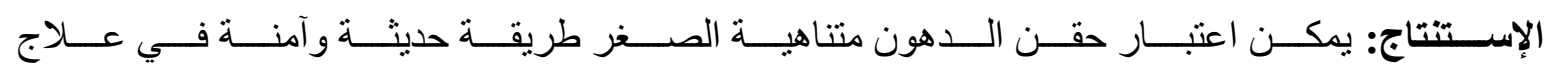

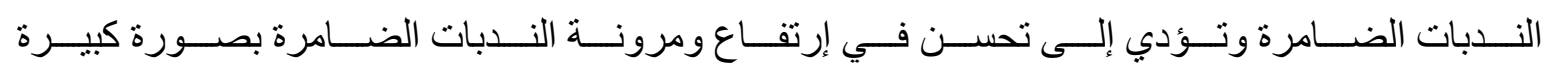

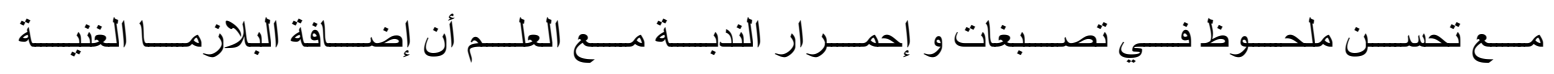

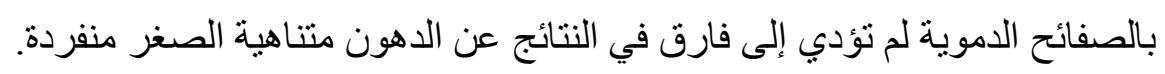

